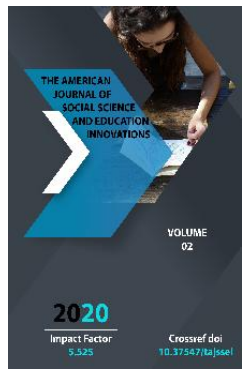

Journal Website: http://usajournalshub.c om/index,php/tajssei

Copyright: Original content from this work may be used under the terms of the creative commons attributes 4.0 licence.

\section{Research Of Terminology And Aviation Terminology}

Nilufar Ergashevna Yuldosheva

Associate Professor Of Uzbek Linguistics, Karshi State University, Uzbekistan

Rano Turaevna Ergasheva

Senior Teacher Of The College Higher Military Aviation Of The Republic Of Uzbekistan, Uzbekistan

\title{
ABSTRACT
}

This article deals with terminology, the formation and development of industry terms, the role of aviation terms in the terminosystem.

\section{KEYWORDS}

Terminology, industry terms, aviation, calca, aviation terms, terminosystem, lexical system.

\section{INTRODUCTION}

Changes in the development of society, scientific, technical, national and cultural developments, first of all, are reflected in the language, its lexical system and are reflected in the terminology of a particular language and enrich it.
Terminology is a very broad and dynamic vocabulary layer of language, which is a set of special names, i.e. terms that express concepts in the field of professional activity of people in science, technology and other social 
fields. It is these terms that are the most important component of any language.

Although terms that have been an integral part of science have existed for a long time, it has not been long since they have been systematically studied and researched.

\section{MATERIALS AND METHODS}

Terminology as a science was formed around the twenties of the twentieth century. Terminology was originally studied as part of lexicology. The Austrian scholar E. Worster was recognized as the founder of the school of terminology after devoting his doctoral dissertation to the lexical units of technical language.

Continuing his work, $\mathrm{H}$. Felber notes that the term "terminology" means three different concepts: 1 . Terminology is an interdisciplinary science, which studies the terms that represent a particular concept, such as symbols. 2. Terminology - a set of terms that describe a system of concepts related to a particular field; 3. Terminology is the promotion of specific field concepts expressed in terms. Terms are scientific, scientific-technical process, words and phrases that express a specific concept in a particular field, perform a special function, as well as specialized units that are semantically limited to a specific field and represent a concept in that field.

Unlike common words, they always serve to express and express specific concepts, and are formed and perfected on the basis of the stages of formation and development of language. Therefore, the terms play an important role in naming and describing scientific concepts in the field of science and technology. After all, each field of science has its own terminological system and deals with them. In particular, in the world terminosystem E. Andrews (1947), T. Savari (1953), R.V. The work of Brown (1954), J.N. Hogg (1954) and E. Allan (1957) on the development and structure of terminology is well known. Units in the terminological system of language are also characterized by sectoral specificity.

Therefore, many terms used in different fields are distinguished by their distinctive features and form specific semantic groups. A number of works by linguists such as S. Sttubelius $(1958,1960)$ and L. Hilbert $(1965,1967)$ on the formation and development of the semantic group of certain terms in world linguistics are devoted to the issues of term and terminology. Also in the Russian terminological system on V.A. Lukashev's shipbuilding, L.Y. Evstikheeva's wedding ceremonies, N.N. Milyuk's archeological terminology, S.M. Kirshoning's finance and credit, E.B. Ershova's criminal law, V.V. Nikitina's business, A.A. Denisova's general law, L.N. Zenkova's military artillery, I.A. Kolesnikova's radio engineering, T.B. Soltakovskaya's diplomatic terms, T.G. Mishina's automotive terminology, L.D. Sidorko's electrical terminology scientific research has been carried out.

\section{RESULT AND DISCUSSION}

As a result of science, technical progress, new discoveries, new terms appear in the language. An example of this is the terminology of the aviation industry. The emergence of aviation terms in world linguistics is associated with the active development of aviation in England and the United States in the early twentieth century. In L. Tkacheva's words, the period of "aviation itself was born, strengthened and developed rapidly" was a decisive factor in the history of 
the development of aviation terminology, and during this period the process of creating aviation terms from English-language materials intensified. Because aviation terminology is relatively young compared to other industry terminology. Although it is about 200 years old, its development dates back to the twentieth century, as mentioned. The history of aviation development is closely linked to the history of aeronautics. Therefore, all stages of historical technical development in aeronautics - from aeronautics to aviation, from aviation to rocket technology and aerospace - are reflected in aviation terminology and cover many terms in other terminological fields. As a result, the associative study and interpretation of adjectives provides a high level of material, source, even to the technical requirements, further increasing the importance of practical lexicography.

In world linguistics, work has begun on the onomasiological and semiotic study of aviation terms, the creation of their terminological system, regulation, linguistic and lexicographic research. In particular, A.Shloman's dictionary of aviation, I.V.Arnold's research work is a prelude to his work in the field of aviation. The scientist I.V.Arnold simultaneously analyzes the methods of making aviation terms in the language, as well as the peculiarities of the English aviation dictionary. Swedish linguist S.Stubelius studies English aviation terms diachronically. Focusing on the general problem of aviation terminology in English in his research, he notes that about 170 terms have been used to convey the concept of "aviation" in different periods of aeronautics and aviation history, and divides these terms into semantic groups and considers each group separately.
Later in the formation and development of terminology in this area, the research work of I.V. Asmukovich, G.O. Vinokur, O.V. Kovtun, V.P. Marasanov, L.B. Tkacheva is noteworthy. In this work, the structural, semantic, derivational, thematic, lexicographic features of aviation terms are studied, which are one of the most pressing issues in Uzbek linguistics today, is now an important resource in the study of the onomasiological and semasiological aspects of terms in the field of budding aviation, in the methods of construction and in the definition of thematic groups. Looking at the above research, we can see that aviation terminology, that is, the system of terms related to the field of aviation, is studied in 4 subsystems: aeronautics, aviation, rocket technology, and aerospace.

Although the aviation industry is actively developed in the UK and the US, most of the terms related to it are not English. The main part of English aviation terminology consists of words in Greek, Latin and French.

For example: Greek, Latin terms: avia [lot.avis- bird], automatic [Greek. automatos self-propelled], autopilot [auto .. + fr. pilot], adjutant [lot. adjutans, adjutantis -assistant], antenna [lot. antenna - a transverse beam on the ship's mast; insect mustache], army [lot. armare - to arm], ballistics [yun.ballo- throw, father], model [lot. modulus -measure, norm], motor [lot. motor - actuator] and etc.

Assimilations in French are much more than terms borrowed from Greek and Latin: avantgarde [fr. avantgarde - front guard], aviation [fr. aviation <lot. avis - bird], azimuth [fr. azimuth - roads, directions; hangar [fr, hangar], artillery [fr. to the artillery - to prepare,], attack [fr. attaque - attack], attashe [fr. attache - attached], battery [fr. batterie $<$ battre - to strike], bomb [fr. bombe <lot. bomb - noise] and etc. 
Russian aviation terminology was formed on the basis of the aviation terminology system of the English language.

In the Russian aviation terminosystem, along with Greek, Latin, French, and English terms, there are also Russian terms: helicopter $[r$. верт(еться) - to turn + лет(ать) - to fly]; platoon [r. From the word «взводит» - high rise]; engine [r. "двигатель" - the engine; excitatory]; fuse [r. запалить - to burn, to set on fire]; device [r. прибор - instrument, device]; receiver [r. принять "to take" noun made from verb].

By the 1970s, Uzbek terminology had also developed and expanded under the influence of assimilations from Indo-European languages through the Russian language. Assimilated terms, especially Russianinternational terms, played an important role in the formation of the system of industry terminology.

In the late twentieth and early twenty-first centuries, great work was done to study the lexicon of the Uzbek language as a system. In this regard, the work of $\mathrm{H}$. Nematov and $\mathrm{R}$. Rasulov "Fundamentals of systemic lexicology of the Uzbek language" and a number of studies based on it are of particular interest. Due to independence, Uzbek terminology is undergoing a process of comprehensive improvement in the era of globalization. This process is also reflected in the terminology system specific to the aviation industry.

A large part of the Uzbek aviation terminology system consists of names derived from Western languages, especially French and English, as well as Russian-international words: airfield, attaché, attack, bomb, brigade, twist, platoon, helicopter, fan, seaplane, engine, landing, detail, division, dynamite, airship, dispatcher, zenith, location, maneuver, model, navigation.
In addition to morphological, semantic and syntactic methods of word formation in the Uzbek language, along with the creation of new terms in the field of aviation, the method of expressing concepts related to foreign languages on the basis of their internal capabilities, i.e. the method of kalkalash. Using this method, some of the terms of assimilation from other languages are replaced or translated into Uzbek. Therefore, this method is distinguished by its convenience and efficiency in naming new concepts.

For example: air strike (удар авиации), aviation weapons (авиационное вооружение), active-jet projectile (активнореактивный снаряд) (active weapon), communication (связь), instruments (приборы), arsenal (арсенал), main forces (главные силы), atomic bomb (атомная бомба), bacteriological (biological) weapon (бактериологическое оружие), bomb shelter (бомбоубежище), bomb shooter (бомбомёm), light signaling (светосигнализация).

\section{CONCLUSION}

It seems that many of the terms used in Uzbek in the field of aviation have been borrowed from other languages, and most of the existing terms are formed mainly on the basis of kalkalash. The ambiguity of the terms indicates that there are no terminological dictionaries in the field of aviation in the Uzbek language and that the field has not been studied monograph. Determining the place of aviation terms in the lexical system of the language, the study of semantic-structural structure and their lexicographic interpretation is one of the most important issues facing Uzbek linguistics today. 


\section{REFERENCES}

1. Wuster E. InternationaleSprachnormung in der Technik, besonders in der Elektronik. Berlin, $1931.431 \mathrm{pp}$.

2. Felber H.Terminological work and standardization of terminology. - Paris, 1974. - P .1.

3. V.A. Lukashev. Scientific and technical terminology of ship design ". Dissertation. Candidate of Philology. L., 1985

4. L.Y. Evstikheeva "The structure and terminology of the wedding ceremony" candidate of philological sciences: 10.02.01/ Saratov. state un-t them. N.G. Chernyshevsky. - Tambov, 1991 -- 268 p.

5. N.N. Milyuk. Archaeological terminology in modern Russian literary language. Dissertation of can. Of phil. Sciences. 1985 249p.

6. S.M. Kirsho. Modern Russian financial and credit terminology as a system. ... Dissertation in Philosophy. Odessa. 1989. 210p.

7. E.B. Ershova. Terms of criminal law. .abstract. diss. ... Cand. philologist, sciences: 10.02.01 / Ershova Elena Borisovna. L., 1990 .-- 14 p.

8. V.V. Nikitin. A systematic description of business terminology in the modern Russian language. Diss. 1991 181p.

9. A.A. Denisova. Semantics of terms of the general theory of law (paradigmatic aspect) author. diss. ... Cand. philologist, sciences: 10.02.01 / Denisova Alla Anatolyevna. - M., 1992.16 p.

10. L.N. Zenkova. Structural and semantic characteristics of military artillery terminology. Abstract dis. ... candidate of philological sciences: 10.02.01 / St. Petersburg. un-t - St. Petersburg, 1991. - 18 p.
11. I.A. Kolesnikov. Functioning of Russian radio engineering terms dis. ... Cand. philol. sciences. - M., 1986 .-- 19 p.

12. T.B.Soltakovskaya. Internationalisms in the diplomatic terminology of the modern Russian language, Dissertation in Philology. L., 1990. 199p.

13. T.G. Mishina. Automotive Terminology in Russian and English Languages, Candidate's Dissertation in Philology, Gorky, 1990.

14. L.D.Sidorko. Dynamics of electrical terminology in the Russian language. dis. ... Cand. philol. sciences. Odessa, 1990.16 p.

15. Tkacheva L.B. The origin and formation of aviation terms in English: dis. ... Cand. philol. sciences. Omsk, $1972.211 \mathrm{p}$.

16. G.N.Tojieva. Conceptual lexicography of tolerance of the linguistic-cultural dictionary "National idea". The culture of tolerance in the context of globalization: methodology of research, reality and prospect Materials of the international scientific conference on May 13-14, 2014. P.-33.

17. Shloman A. Illustrated technical dictionary in six languages: German, English, French, Russian, Spanish. Cars, motor boats, snowmobiles, airplanes. SPb : Culture, $1910.1036 \mathrm{p}$.

18. Arnold I.V. English aviation technical lexicology: dis. Cand. philol. sciences. M., 1944.132 p .Arnold I. V. Semantic structure of the word in modern English and methods of its research. L .: Education, $1966.192 \mathrm{p}$.

19. S. Stubelius. Airship, Airplane, Aircraft (1958) and Balloon, Flying-Machine, Helicopter (1960).

20. Asmukovich I. V. Formation and development of English aviation terminology // Science Bulletin of the Volynsky National University of the Ukrainian Forest. 2011. No. 6. P. 112- 
Doi: https://doi.org/10.37547/tajssei/Volume02Issue08-51

117.Kovtun O.V. Formation of professional development in the future of aviation galusies: monograph. $\mathrm{K}$.: Osvita Ukrainy, 2012.448 p. Marasanov V.P. The EnglishRussian Dictionary of Civil Aviation. $M$.: Scorpio-Russia, 1996.560 p. Tkacheva LB The origin and formation of aviation terms in English: dis. ... Cand. philol. sciences. Omsk, $1972.211 \mathrm{p}$. 